УДК 32

DOI $10.21661 / \mathrm{r}-116657$

\title{
М.М. Маткаримов
}

\section{ОСОБЕННОСТИ СОЦИАЛЬНОЙ ПОЛИТИКИ В КЫРГЫЗСТАНЕ}

Аннотация: в статье анализируются сочиальные последствия радикальных экономических реформ, проведенных в суверенном Кыргызстане, и прочессы преобразования сочиальной сферы, направленные на преодоление этих последствий. Акиент делается на углубление бедности как массового явления в Кыргызстане на основе данных социологических исследований.

Ключевые слова: идеологические дискуссии, бедность, соииальная политика, демократическое государство.

\section{M.M. Matkarimov}

\section{CHARACTERISTICS OF SOCIAL POLICY IN KYRGYZSTAN}

Abstract: the article analyzes the social consequences of the extreme economic reforms, conducted in sovereign Kyrgyzstan and the processes of social transformations, helping to overcome these consequences. An accent is made on deepening of poverty as a mass phenomenon in Kyrgyzstan on the basis of sociological researches.

Keywords: ideological discussions, poverty, social politics, democratic state.

Анализ и изучение данной проблемы определяются комплексом теоретических и практических вопросов, связанных с определением степени удовлетворенности населения проводимой социальной политикой, соответствия уровня социальных ожиданий общества уровню социальной защищенности граждан, соблюдением условий получения реальной социальной помощи и гарантированного объема социальных услуг.

Социальная политика государства объективно требует учета жизненных реалий и ситуаций в экономической сфере, как в глобальном, так и в локальном масштабе. Опыт стран, осуществивших социально-экономические, социально- 
политические преобразования демонстрирует, что успешное завершение всех реформ зависит не только от модели социального развития, но и от выбора собственного курса и концепции социальной политики. В Кыргызстане, с учетом накопленного опыта, национальной специфики разработана своя модель социального развития. В этой связи проблема социальной политики приобретает значимость не только в качестве элемента или контекста социально-политической действительности, но и в аспекте рассмотрения ее социальных функций в обществе как атрибута любых социально-политических трансформаций.

В совокупности все обозначенные обстоятельства подводят к постановке и решению вопроса об изменении функциональных задач государства в условиях социально-политической модернизации, об определении его роли как субъекта социальной политики, формирования нового качества самой социальной полиТики.

Изучение вопросов социальной политики является приметой последних лет для отечественной науки и социально-управленческой практики. Социальные последствия радикальных экономических реформ, проведенных в суверенном Кыргызстане, проявились в снижении уровня жизни подавляющей части населения и ухудшении его качественных параметров. А так же активно осуществляющиеся преобразования социальной сферы, направленные на преодоление этих последствий, привели к тому, что ключевые аспекты социальной политики в настоящее время стали предметом острых научных, политических и идеологических дискуссий. За последние годы в отечественной науке и социально-управленческой практике накоплен значительный эмпирический и теоретический материал, позволяющий начать процесс методологической рефлексии социальной политики на системно-качественном уровне.

Социальная политика по определению бедности устанавливается на основании данных социологических исследований: во-первых, бедность человека или же семьи - это, прежде всего, экономическое явление, так как в массовом сознании населения бедность рассматривается как невозможность иметь те материальные средства, которые имеют семьи с высоким доходом. Также и понятие 
«средство» (заработная плата, пенсия, пособие и т. д.) идентифицируется с доходом семьи.

Во-вторых, бедность - это политическое явление, ибо материальный недостаток человека или семьи приводит к лишению возможности их участия в принятии важных решений властями. Поэтому углубление или обострение бедности может привести общество на определенном уровне к социальной напряженности и дестабилизации.

В-третьих, если материальный недостаток человека или семьи, как правило, приводит к низкому уровню культуры и нравственности, то данная проблема бедности рассматривается как духовное явление, потому что крайне бедные в борьбе за выживание не замечают снижение уровня образования, культуры, духовности и поведения.

В-четвертых, бедность считается особым психологическим состоянием, так как человек, неспособный удовлетворить свои материальные, духовные, политические потребности, становится индивидом с заниженной самооценкой, чувствует себя несвободным, не получает от жизни должного удовольствия, лишается чести и достоинства, не заслуживает уважения окружающих его людей. В итоге в нем формируется комплекс неполноценности.

Определение понятия «бедности» является очень сложной проблемой. В мировой практике существуют официальные официальная (объективная) и неофициальная (субъективная) концепции (способы) определения бедности.

Согласно первой концепции бедность определяется на государственном уровне на основе официальных исследований (оценка экспертов), а согласно второй - бедность исследуется путем опроса общественного мнения.

В соответствии с первой концепцией в качестве критерия бедности принят минимальный потребительский бюджет или прожиточный минимум (набор продовольственных и непродовольственных товаров и услуг в натуральном и стоимостном выражении, обеспечивающий человеку потребление на уровне, принятом обществом в качестве минимально допустимого на данном этапе его развития, определяемый научно обоснованными нормами и нормативами), согласно 
которому устанавливаются масштабы бедности (процентное выражение той части населения, которая находится в состоянии бедности), порог бедности и категории бедных.

В целях преодоления бедности была создана национальная программа «Аракет» (1998-2005 гг.), в которой бедная часть граждан республики условно разделена на две категории.

Если первую категорию бедных составляют нетрудоспособные граждане и другие социально уязвимые группы населения, то вторую группу составляют семьи трудоспособных граждан - низкооплачиваемые работники, часть людей, имеющих небольшие земельные наделы и безработные.

Во многих странах при глубоком и разностороннем исследовании бедности, наряду с официальной концепции, практикуется неофициальная (субъективная). В Кыргызстане согласно субъективной концепции (данные ряда крупных социологических исследований 1997, 1999, 2003-2010 гг.) было подтверждено, то что бедность стала социальным явлением, которое проникло во все сферы жизнедеятельности человека и коренным образом изменило его образ жизни.

Возникновение в Кыргызстане бедности, которая становится массовым явлением, обусловлено рядом причин. Если в первые годы суверенитета Кыргызстана респонденты видели основные причины бедности только во внешних факторах, то позже они пытались определить и другие реальные причины. Например, по данным социологических исследований (Всемирный банк 1999), респонденты отмечают, что бедность является порождением переходного этапа, когда существуют объективные факторы (безработица, дороговизна, несвоевременная выплата пенсий, пособий; реформы, упущения и недостатки при приватизации и т. д.), а также субъективные факторы (лень, безделье, безынициативность, иждивенчество, алкоголизм, излишние расходы при проведении национальных обычаев и традиций). Бедность в значительной степени больше распространена в сельской местности, чем в городской.

В настоящее время категория бедных охватывает большую часть населения. В нее входят: городские бедные, семьи, не имеющие возможность купить 
одежду, нуждающиеся в питании, зачастую страдающие недоеданием, не имеющие возможность дать должного воспитания и образования своим детям.

Сельские бедные не имеют скота (некоторые могут иметь корову, одну-двух овец, несколько кур), проживают в ветхих домах, не имеют возможности обрабатывать свои земельные наделы, испытывают постоянный недостаток в пропитании и одежде, дети часто пропускают занятия или бросают школу совсем, в результате чего возникают конфликты в таких семьях из-за материальных затруднений.

Бедность оказывает отрицательное воздействие на материальное, моральное, психологическое состояние всех членов семьи, в особенности на формирование подростковых детей, у которых вместо раскрытия потенциальных возможностей формируется комплекс неполноценности. Поэтому задачей демократического государства является сокращение числа бедных и решение проблемы преодоления бедности.

\section{Сиисок литературы}

1. Эдилова М.М. Бедность - как социальное явление. - Бишкек, 2001.

2. Холостова Е.И. Социальная политика. - М., 2001.

3. Маматов А. Основные направления модернизации социальной сферы Кыргызстана. - Бишкек, 2005.

Маткаримов Муратбек Маткаримович - аспирант, преподаватель Бишкекского гуманитарного университета им. К. Карасаева, Кыргызстан, Бишкек.

Matkarimov Muratbek Matkarimovich - postgraduate, lecturer of K. Karasaev Bishkek Humanitarian University, Kyrgyzstan, Bishkek. 